\title{
Polish Economists in Nehru's India: Making Science for the Third World in an Era of De-Stalinization and Decolonization
}

\author{
Małgorzata Mazurek
}

During trips to India in 1955 and 1956, Oskar Lange (1904-1965), an internationally renowned Polish economist and diplomat, became an unlikely confidant of Indian Prime Minister Jawaharlal Nehru. Lange helped to shape the planning parameters and socialist rhetoric for India's Second Five-Year Plan (1956-1961), and the Polish press reported that when Nehru presented the Plan to the Indian Congress Party he "spoke in Lange's words."1 In Lange's eyes, such a privileged relationship placed him in a tricky position. From his diplomatic experience as socialist Poland's first ambassador to the United States and the United Nations, he understood that an economic adviser's role was never apolitical. Lange represented the eastern bloc, and he reasoned that if his role in the planning process became too prominent, it might diminish the chances of success for Nehru's Soviet-style industrialization, as the project already faced strong opposition from local interest groups and the United States. ${ }^{2}$ He viewed an unfavorable outcome as a diplomatic and personal failure. So when Nehru invited Lange to a private meeting with Indian ministers, Lange had to convince him that the "presence of a foreigner from a country of a very distinct ideology could be criticized by more conservative members of the cabinet." 3 Nehru eventually dropped the idea, but he insisted on giving Lange special treatment and threw him a large farewell party-an extraordinary gesture, since India had no shortage of foreign advisers. In the mid-1950s, the Planning Commission and other Indian institutions hosted

I would like to thank Theodora Dragostinova and Małgorzata Fidelis, the organizers of this cluster and of the conference at the Ohio State University "Iron Curtain Crossings: Eastern Europe and the Global Cold War." I also want to thank the organizers and participants of the Columbia University workshop "Global Circuits of Expertise and the Making of the Post-1945 World: Eastern European and Asian Perspectives,"” where I discussed the preliminary version of this article; my colleagues Deborah Coen, Kavita Sivaramakrishnan, and Maria Bucur for their helpful feedback and suggestions; anonymous reviewers; and finally Ignacy Sachs, who first told me about Polish economists in India.

1. Widzaj Soni, “Oskar Lange i planowanie w Indiach,” Polityka, no. 48; Oskar Lange, Dzieła, vol. 8, (Warsaw, 1986), 555-56; Maciej Tumulec, Historia stosunków polsko-indyjskich XVI-XXI w. (Warsaw 2013), 66.

2. On Indian economic policy and planning in a national context, see B. R. Tomlinson, "The Economy of Modern India: From 1860 to the Twenty-First Century," in The New Cambridge History of India, $2^{\text {nd }}$ Ed. (Cambridge, Mass., 2013). On the role of international actors in India's developmental policy, see David C. Engerman, The Price of Aid: The Economic Cold War in India (Cambridge, Mass., 2018); Corinna R. Unger, Entwicklungspfade in Indien: eine internationale Geschichte 1947-1980 (Göttingen, 2015).

3. Polish Ministry of Foreign Affairs Archive (Archiwum Ministerstwa Spraw Zagranicznych, herafter AMSZ), 12/9/218 (Notatki z pobytu w Indiach rektora Szkoły Głównej Planowania i Statystyki, Oskara Lange, 26.01-15.04.1955, Notatka no. 4, March 30, 1956, npag); AMSZ, 12/9/218 (Notatki z pobytu w Indiach rektora Szkoły Głównej Planowania i Statystyki, Oskara Lange, 26.01-15.04.1955, Notatka no. 5, May 2, 1956, npag). 
around four hundred foreign experts from the United States, the Soviet Union, France, Germany, and elsewhere. All of these experts worked on the Second Plan, but few were accorded Lange's significance and honors. ${ }^{4}$

Lange's return to Poland in April 1956 coincided with an event that shook the Polish public: Nikita Khrushchev's revelations about Stalin's crimes. ${ }^{5}$ Throughout the country, de-Stalinization and soul-searching were in full swing; at gatherings of intellectuals and meetings of local party committees, calls for "democratization" rang out. At one such venue, the Second Convention of Economists, Lange cast off his Stalinist persona. ${ }^{6}$ Although critics characterized his opening speech as "torpid," two days later he changed his tone and vigorously advocated for an open Marxism.

The second half of the 1950s was crucial to the global construction of the modern nation-state through science and economic policy. At that time, two variants of state-led modernization-socialist planning and developmental politics as anti-colonial practice-came together thanks to the new Soviet Third World policy. Abandoning the Stalinist vision of the world as rigidly divided into antagonistic camps, the Soviet Union and its east European allies began to spread activist modernization outside the bloc and hoped to advance a socialist agenda on a global scale. ${ }^{7}$ The Soviets developed the concept of "peaceful coexistence" that denoted the eastern bloc's (largely) nonviolent yet competitive strategy for adapting to decolonization and the rise of the non-alignment movement. ${ }^{8}$ The strategy forged new ties between Poland and India. De-Stalinization and decolonization allowed Polish economists like Lange to depart from Stalinist economic orthodoxy, distance themselves from the Soviet bloc's Cold War politics, and join transnational networks that theorized ways to improve the lives of the rural poor around the world.

4. David C. Engerman, "Learning from the East: Soviet Experts and India in the Era of Competitive Coexistence," Comparative Studies of South Asia, Africa and the Middle East 33, no. 2 (2013): 230.

5. Csaba Békés, "East Central Europe, 1953-1956," in Melvyn Leffler and Odd Arne Westad, eds., The Cambridge History of the Cold War Vol. 3: Endings (Cambridge, Mass., 2010), 343; Paweł Machcewicz, Rebellious Satellite: Poland 1956, trans. Maya Latynski (Washington D.C., 2009). For a new comparative perspective, focusing on intellectual and social aspects of the early post-Stalinist era in Poland, Czechoslovakia, and East Germany, see Pavel Kolář, Der Poststalinismus: Ideologie und Utopie einer Epoche (Cologne, 2016).

6. The Second Convention took place on June 7-9, 1956. For an excellent historical analysis of the conference and the politics of institututional changes in post-1945 Polish economics, see Aleksandra Witczak Haugstad, A Discipline Divided: Polish Economists and the Communist Regime, 1945-1960 (Ph.D. diss., Norwegian University of Science and Technology, 2008).

7. Michael E. Latham, "The Cold War in the Third World, 1963-1975," in Melvyn Leffler and Odd Arne Westad, eds., The Cambridge History of the Cold War, Vol. 2: Crises and Detente (Cambridge, Mass., 2010), 258-80; James Mark, Steffi Marung and Artemy M. Kalinovsky, eds., Alternative Globalizations: Eastern Europe and the Decolonizing World (Bloomington, forthcoming).

8. Leslie James and Elisabeth Leake, eds., Decolonization and the Cold War: Negotiating Independence (London, 2015); Robert J. McMahon, "On the Periphery of a Global Conflict: India and the Cold War, 1947-1991," in Andreas Hilger and Corinna R. Unger, eds., India in the World Since 1947: National and Transnational Perspectives (Frankfurt am Main, 2012), 276-99. 
Significantly, the visits Lange and other foreign experts made to India in the late 1950s did not occur through military intervention. Instead, they focused on diplomacy and scholarly expertise. Rather than arriving in Delhi or Calcutta armed with guns, these experts mostly submitted memoranda and trade deals, and sat on advisory committees. In the late 1950s, political leaders and intellectuals saw Third World development politics, associated with a "domestication of the future" through science, as a hopeful sign. ${ }^{9}$ Development politics had not yet become linked to what Albert O. Hirschman later called "development disasters."10 Moreover, the Cold War superpowers' coercion, armed intervention, and blatant support for military dictatorships did not yet dominate Third World politics. The decisive global turn to insurgency occurred only in the mid-to-late 1960s. Because economic expertise-next to engineering, urban planning, and architecture-became Poland's key export product and diplomatic currency in the Third World between 1956 and 1968, the epistemic and intellectual effects of these encounters are especially relevant. ${ }^{11}$

As de-Stalinization progressed and Soviet Third World politics expanded, Polish economists' relationship with India became crucial to the evolution of their ideas. Polish leading economists theorized "backwardness," "underdevelopment," and Poland's place in the world in three distinct ways. First, they reassessed the politics of accelerated modernization that emerged from observing the failures of, and obstacles to, Polish and Indian economic transformations. Second, because of the dominance of smallholder farming in India and its revival in 1956 Poland, they shifted attention to the apparent durability of the "peasant economy" vis-à-vis "socialist" and "capitalist" industrialization. Finally, they interacted with economists and Marxist scholars also living or sojourning in India, interactions which helped to soften Eurocentrism in Polish social science.

It is important to note that this post-1956 expert conversation and the transnational conception of shared Polish-Indian modernity arose separately from the Soviet discourse about "solidarity with the oppressed peoples and victims of imperialism." 12 As Poland gained the leeway to set a more independent political and intellectual agenda, radical opposition to agrarian collectivization formed, placing Poland's agrarian policy closer to that of India rather than China or the Soviet Union. ${ }^{13}$ Moreover, the 1956 "Polish October," the

9. Jenny Anderson, "The Great Future Debate and the Struggle for the World," American Historical Review 117, no. 5 (December 2012): 1411-30.

10. Albert O. Hirschman, "The Rise and Decline of Development Economics," in The Essential Hirschman, ed. and introduction by Jeremy Adelman (Princeton, 2013), 68.

11. For a comparable analysis of in the field of architecture, see Łukasz Stanek, "Introduction: The 'Second World's' Architecture and Planning in the 'Third World', in "Cold War Transfer: Architecture and Planning from Socialist Countries in the 'Third World', a special issue of The Journal of Architecture 17, no. 3 (June 2012): 299-307; Stanek, "Miastoprojekt Goes Abroad: The Transfer of Architectural Labour from Socialist Poland to Iraq (1958-1989)," The Journal of Architecture 22, no. 4 (June 2017): 786-811.

12. On the shifting Soviet discourse about Latin America, Asia and Africa, see Silvo Pons, The Global Revolution: A History of International Communism, 1917-1991, trans. Allan Cameron (Oxford, 2014).

13. Nigel Swain, "Eastern European Collectivizations Campaigns Compared, 1945-1962," in Constantin Iordachi and Arnd Bauerkamper, eds., The Collectivization of 
regime's relatively peaceful liberalization, strengthened the affinity between Oxbridge-educated economists in Poland and India. Their practical exchange of knowledge reflected the genuine lack of personal, intellectual, and political barriers between the Polish experts, their Indian hosts, and western scholars working in India. In the late 1950s, the quest for modernization, planning, and land reforms came to be seen as common ground between eastern Europe and South Asia. This article shows how this shared perception evolved.

I also argue that in Nehru's India, developmental thought's material implementation was neither the only, nor the main, criterion for why certain ideas mattered. ${ }^{14}$ "Development Politics," David Engerman's term for the novel mix of international relations, expertise, and financial assistance that emerged during the global Cold War, did not only concern the effective deployment of technical expertise. ${ }^{15}$ Leaders like Nehru treated the presence of international experts as an ineluctable part of Cold War diplomacy, and often let their memoranda gather dust-a fact that Polish economists were well aware of. ${ }^{16}$ Despite some governmental neglect, by participating in an intellectual network that spanned the postcolonial world, Polish scholars contributed to key global currents of the 1960s, such as peasant studies and the critique of modernization theory. As most historians note, the early Cold War internationalization of Polish social science was not merely due to contacts with the west. The postcolonial world also contributed to and enriched this internationalization. ${ }^{17}$ My argument accords with recent historiography that looks at "longer, deeper, and wider" histories of development and opposes the assumption that this history belongs only to the west. ${ }^{18}$

I begin with Lange's discussion of post-colonial India during the winters of 1954-55 and 1955-56, when he acted as an economic adviser to Nehru. Lange's intellectual diplomacy and Poland's de-Stalinization set the stage for a uniquely intense exchange between Polish economists and Indian

Agriculture in Communist Eastern Europe: Comparison and Entanglements (Budapest, 2014), 526-29; Shen Zhihua and Li Danhui, "The Polish Crisis of 1956 and Polish-Chinese Relations," in Jan Rowinski, Tytus Jaskułowski, and Polski Instytut Spraw Międzynarodowych, eds., The Polish October 1956 in World Politics (Warsaw, 2007), 75-114.

14. Engerman, "Learning from the East"; David C. Engerman, "The Political Power of Economic Ideas? Foreign Advisors and Indian Planning in the 1950s and 1960s," in Hilger and Unger, India in the World, 120-35.

15. David C. Engerman, "Development Politics and the Cold War," Diplomatic History 41, no. 1 (January 2017): 1.

16. Ignacy Sachs, "Learning Political Economy with Michał Kalecki," Review of Political Economy 11, no. 3 (July 1999): 269-70.

17. Volker R. Berghahn, America and the Intellectual Cold Wars in Europe (Princeton, 2001); Igor Czernecki, "An Intellectual Offensive: The Ford Foundation and the Destalinization of the Polish Social Sciences," Cold War History 13, no. 3 (August 2013): 289-310; Antoni Sułek, “'To America!' Polish Sociologists in the United States after 1956 and the Development of Empirical Sociology in Poland," East European Politics and Societies: and Cultures 24, no. 3 (March 2010): 327-52; Maxine Berg, "East-West Dialogues: Economic Historians, the Cold War, and Detente,” The Journal of Modern History 87, no. 1 (March 2015): 36-71.

18. Joseph Hodge, "Writing the History of Development (Part 2: Longer, Deeper, Wider)," Humanity: An International Journal of Human Rights, Humanitarianism, and Development 7, no. 1 (Spring 2016): 125-74. 
planners. The years 1957-60 heralded the golden age of Polish intellectual engagement in Third World politics, in which the Polish embassy in Delhi played a pivotal role. I then discuss one example of these exchanges: the interaction between Ignacy Sachs, a young Polish diplomat and social scientist, and Daniel Thorner, an American scholar residing in India whose writings on land reforms in colonial and postcolonial "Indian villages" had a significant impact on Polish developmental thought. Next, I examine Michał Kalecki's trip to India in 1959-60. Kalecki's experiences in India confirmed the importance of smallholder peasantry to the economy and for developmental thought in general. His work also marked the shift from a Stalinist discourse of accelerated industrialization to heterodox conceptualization of Third World regimes of development. I conclude by presenting the epistemic effects of the overlapping de-Stalinization of Polish science and the opening of the eastern bloc to the decolonizing world.

\section{Oskar Lange: Stalinism, Economic Diplomacy and India's Bid for Accelerated Modernization}

During the mid-1950s, India began to establish itself as a democratic leader of the emerging non-aligned movement. It was also a unique geopolitical space: one of the Cold War's key battlegrounds, where diverse paradigms of technical assistance and economic modernization were introduced and disputed. ${ }^{19}$ Lange, who rejected a professorship at the University of Chicago to work for the postwar Polish state, was one of the first celebrities of international economics to be courted by Nehru's planning strategist and director of the Indian Statistical Institute (ISI), Prasanta Chandra Mahalanobis. Lange and Mahalanobis may have been introduced around 1946 or 1947 at the United Nations, where Lange served as the Polish representative to the United Nations and Mahalanobis served as a member of the UN Statistical Commission. ${ }^{20}$ In July 1952, Mahalanobis invited Lange to spend a year at the ISI; unfortunately, the timing was bad, as Stalin then considered India nothing more than "a tool of Anglo-American imperialism" and saw the (post)colonial world as "at best a sideshow, and at worst a distraction." ${ }^{21}$ After Stalin's death, however, the Soviet Union made a remarkable volte-face in its policy toward the Third World, and began to see India as its principal partner in the effort to weaken the western "camp." Lange eventually visited ISI in late 1954, where along with experts from the Soviet Union, France, the United Kingdom, and elsewhere, he assisted India's drive toward industrialization. ${ }^{22}$

19. Engerman, The Price of Aid; Unger, Entwicklungspfade in Indien; Nick Cullather, The Hungry World: America's Cold War Battle Against Poverty in Asia (Cambridge, Mass., 2010), in particular chapter 3.

20. United Nations Statistical Commission: Sixty Years of Leadership and Professionalism in Building the Global Statistical System, 1947-2007 (New York, 2007), 3.

21. Odd Arne Westad, The Global Cold War: Third World Interventions and the Making of Our Times (Cambridge, 2005), 280.

22. Westad, The Global Cold War, 281 and 423-33; McMahon, "On the Periphery of a Global Conflict,” 285. 
Lange, who between December 1954 and April 1956 spent half a year altogether in India, played a double role in this international arrangement. As an economic expert, he drafted papers and memoranda concerning India's Second Five-Year Plan. He also published widely: his articles appeared in prestigious national journals such as Economic and Political Weekly and Sankhya that were read by the Indian progressive intelligentsia, and in economic departments' curricula. ${ }^{23}$ Yet, from the beginning his role in these Second-Third World encounters also involved politics and diplomacy. In Poland, Lange held key positions in academia and the party-state apparatus. Since the late 1920s, he had been an active participant in the Polish Socialist Party's radical wing and during Stalinism he became the president of the Higher School of Planning and Statistics in Warsaw, as well as a member of the Central Committee of the Polish United Workers' Party (PUWP). In India, Lange was quickly instrumental in enhancing Polish-Indian diplomatic relations while simultaneously shaping the Polish version of the communist discourse about "economically backward countries."24 This discourse formed while Lange still maintained a Stalinist persona, and while Poland remained committed to the Stalinist doctrine that communist regimes-with their allegiance to Soviet-style industrialization-were superior to "backward," “capitalist” India.

I draw on both Lange's reports from India to the Polish Ministry of Foreign Affairs and on his official speeches to trace his creation of the official discourse about the Third World on the eve of de-Stalinization. Lange's experiences in India, I argue, demonstrate the relative social insulation of many of Nehru's advisers. This insulation-and the correspondingly superficial understanding of India-caused Lange to project knowledge gleaned from interwar agrarian Poland on India's backwardness. The final effect was Lange's politically ambiguous style of advisorship. On the one hand, Lange officially affirmed the myth of Stalinist modernization and participated in the Soviet discourse that ranked countries according to their commitment to state-socialist industrialization. ${ }^{25}$ On the other hand, Lange's practical recommendations for Mahalanobis and Nehru indicate that his thoughts and advice about underdevelopment and industrialization were more heterodox and distant from official Marxism-Leninism than he would have publicly admitted.

In India, Lange lived the life of an academic celebrity. In early 1956, during his second, four-month stay, he and his wife, Felicja, resided in Calcutta

23. Oskar Lange, Essays on Economic Planning, with foreword by P.C. Mahalanobis (Calcutta, 1958); "Some Observations on Input-Output Analysis," Sankhya: The Indian Journal of Statistics 17, no. 4 (1957): 305-36; "Marxism and Bourgeois Economics," Enquiry 1 (Delhi, 1959; Bombay, 1963); "The Political Economy of Socialism," Economic Weekly 15 (1958): 509-14; "The Role of Planning in Socialist Economy," The Indian Economic Review 4, no. 2 (August 1958): 1-15; Prabhat Patnaik, "Delhi School Days," in Dharma Kumar and Dilip Mookherjee, eds., D. School: Reflections on the Delhi School of Economics (Delhi, 1995), 119.

24. Oskar Lange, “Problem krajów gospodarczo słabo rozwiniętych,” in Dzieła: Kapitalizm, vol. 1, (Warsaw, 1973, [originally published in 1960]), 765-87.

25. On the ideological premises of Soviet expansion in the Third World in the early and mid 1950s, see: Pons, The Global Revolution, 231-33; Westad, The Global Cold War, 104. 
in a guest room designed for the late Rabindranath Tagore, a Bengali poet and the first non-European Nobel Prize laureate in literature. As programmed activities filled his schedule, Lange had little time for independent research on Indian economics and society. ${ }^{26}$ Like most foreign advisers invited to Nehru's India, he relied on data supplied by his hosts. In his leisure time, Lange visited the Taj Mahal and the brand-new Bhakra-Nangal Dam. He also spent several days in Darjeeling "seeing the Himalayas and visiting tea plantations ... a purely touristic trip," he explained. ${ }^{27}$

Although Lange later made bold claims about the state of Indian agriculture, he spent only a few hours in the Indian countryside: "In Mysore and Hyderabad we were taken to a village. We talked to peasants and saw their houses," he wrote drily. ${ }^{28}$ In that day's report, Lange expressed more enthusiasm about the famous Russian writer Il'ia Erenburg, whom he met later that day at a large party that Nehru organized. Among foreign experts, such a superficial inspection of India was more rule than exception. As one foreign resident in India noted about a group of experts, "a dozen busy Americans, some of distinction in agricultural studies and services, flew out from the States [to India] in January. . . . Ten weeks was all that they could spare from the pressure of their normal duties. They made whirlwind tours of India, got their Report ready by April 3, and flew off again." 29

Lange was one of the experts making "whirlwind tours of India," and this superficial acquaintance with India's complex reality affected the way he thought about Third World (under)development. In saying this, I don't wish to imply that more ethnographically-oriented research would automatically allow Lange to acquire a "deeper" and more "real" knowledge of India. But the lack of depth in his approach caused him to rely on preexisting epistemic dispositions and knowledge of "rural backwardness." He therefore relied heavily on historical comparisons and references to prewar, capitalist Poland and eastern Europe; India's situation "is similar to the one we had here in the thirties," he told a Polish audience in July 1955. He continued, "Seventy percent of these people are smallholder farmers, most of them rural proletariat. Secondly, [I was struck by] an extremely low living standard of that multitude. And thirdly, by the huge social contrasts." ${ }^{30}$ Lange took as a template the classbased discourse on Great Depression-era Poland created by Polish Marxist economists and statisticians-a country of smallholder peasantry, handi-

26. AMSZ, 12/9/218 (Notatki z pobytu w Indiach rektora Szkoły Głównej Planowania i Statystyki, Oskara Lange, npag).

27. Engerman, "Learning from the East," 40.

28. AMSZ, 12/9/218 (Notatki z pobytu w Indiach rektora SGPiS, Oskara Lange, 1956, Notatka no. 2, 27.I.1956, npag).

29. Daniel and Alice Thorner, "Ploughing the Plan Under," in Land and Labour in India (Bombay, 1962), 113. The remark concerns the Report on India's Food Crisis and Steps to Meet It by the Agricultural Production Team sponsored by the Ford Foundation (Delhi, 1959).

30. Polish Academy of Sciences Archive (Archiwum Polskiej Akademii Nauk, hereafter APAN), Oskar Lange collection, 130 (Niektóre zagadnienia współczesnych Indii. Odpowiedzi tow. Prof. Lange na pytania prelegentów, Centralny Ośrodek Szkolenia Partyjnego PPZR, July 1955, npag). For the overall account of Lange's trips to India see: Oskar Lange, Dzieła, vol. 3, 541-56. 
crafts, class contrasts, and hidden rural unemployment. ${ }^{31}$ "A characteristic phenomenon in the backward country, known also from interwar Poland, is a huge number of small shops in the cities," Lange wrote in an essay about the concept and politics of modern economic backwardness. "The owner of the small shop sits next to a few jars filled with bon-bons, a couple of shoelaces and other merchandise of that kind, waiting for hours until a client comes and buys something. ... In the countryside, many farmhands are not fully made use of, because the plots are too small to effectively employ the whole family of the owner." 32

In claiming that Poland's past was India's present and Poland's present was India's future, Lange presented the Soviet Union and the eastern bloc as a space of civilizational maturity that decolonizing nations were encouraged to join. ${ }^{33}$ This kind of ideological and teleological generalization exemplified a broader attitude in the Soviet Union (as in the United States and Mao's China) to portray decolonization in linear terms, as "evidence of history's global direction." ${ }^{34}$ In other words, socialism was a historical necessity. As Khrushchev argued, "the triumph of the Soviet system and communism over the ruins of European colonialism" was simply a matter of time, charting an overarching narrative of progressive, national anti-imperialism. ${ }^{35}$ In a 1957 lecture given by Lange, "backward countries" functioned as examples for what would have happened if Poland had remained in capitalism's orbit. ${ }^{36}$ If not for its accelerated industrialization, Poland-like India-would still grapple with "the lack of capital, mass unemployment (official and disguised), petty trade as an important source of the population's income, and various forms of speculation and usury." ${ }^{37}$ Lange's official interpretation of India as presented in Poland was strictly ideological: it aimed, above all, to legitimize the state socialist project.

31. For Marxist and structuralist descriptions of Poland in the world context, see Ludwik Landau, Gospodarka światowa: Produkcja i dochod spoleczny w liczbach (Warsaw, 1939). For other interwar east central European examples of Marxist and structuralist interpretations of "backward economies," see Małgorzata Mazurek, "Measuring Development: An Intellectual History of Ludwik Landau's Scale of World Inequality," Contemporary European History (forthcoming in Fall 2018); Joseph Love, Crafting the Third World: Theorizing Underdevelopment in Rumania and Brazil (Stanford, 1996).

32. Lange, "Problem krajów gospodarczo słabo rozwiniętych," in: Dzieła: Kapitalizm, vol. $1,765-87$, here 767.

33. Andreas Hilger, "Building a Socialist Elite? Khrushchev's Soviet Union and Elite Formation in India," in Jost Dülffer and Marc Frey, eds., Elites and Decolonization in the Twentieth Century (Basingstoke, 2011), 262-86. On the declared superiority of the Soviet economic model in the context of Cold War development, see Alessandro Iandolo, "The Rise and Fall of the 'Soviet Model of Development' in West Africa, 1957-64," Cold War History 12, no. 4 (December 2012): 683-704.

34. Latham, "The Cold War in the Third World," 259.

35. Pons, The Global Revolution, 233, 54; John Riddell, ed., To See the Dawn: Baku, 1920: First Congress of the Peoples of the East (New York, 1993).

36. Oskar Lange, "Dlaczego kapitalizm nie potrafi rozwiązać problemu krajów gospodarczo zacofanych" (na podstawie stenogramu wykładu na kursie Wydziału Propagandy i Agitacji KC PZPR), in Dzieła, vol. 1, [originally published in 1957], 732-33.

37. Ibid.,734. 
In his specific recommendations to the Indian government, however, Lange was eclectic. In a memorandum entitled "Some Remarks on India's Second Five-Year Plan," he proposed a method for introducing industrial planning and encouraging a strong public sector "without undermining the framework of capitalist society." ${ }^{38}$ Lange even pointed to the British war economy and Nazi Germany's economic plans from the 1930s as important models. He based his planning strategy on "mass mobilization" and advocated public investment in heavy industrialization. Yet it was a planned "capitalist state economy"-not a state socialist one-that was the goal.

Nonetheless, Lange simultaneously attempted to tune in to the epic ambitions of Nehru, who-inspired by Mao's China-wanted the Second Five-Year Plan to be a dramatic accomplishment. ${ }^{39}$ Planning was a "word that tantalizes everyone in India," Lange observed, because it contained the promise of lifting India up from its past "sluggishness" and freeing it from "imperial ties" of all kinds. ${ }^{40}$ Lange saw the pace of rural change, in motion since 1952 and assisted by American and German experts, as slow, even snail-paced..$^{41} \mathrm{He}$ thought of agriculture merely as something to be subsumed by the larger task of heavy industrialization that should be achieved through the mobilization techniques typical of a war economy. Despite Nehru's grandly-expressed ambitions, Lange's Indian hosts did not take Lange's epic idea of state-led industrialization literally and Nehru's socialist rhetoric remained just rhetoric. ${ }^{42}$

A skillful diplomat, Lange habitually masked his personal views. His official discourse on "backward" India and the superiority of Polish state socialism should be taken with a grain of salt. Interestingly, Lange befriended and spent a great deal of time with C. D. Deshmukh, Nehru's Minister of Finance, even though in an official report from February 1955 he described Deshmukh as someone who "tried to hinder bold, state-led industrialization" and was tied to "the international monopoly" and the politics of "economic liberalism." 43 In the Poland of early 1955 it is certain that Lange meant none of these descriptions as a compliment.

Whatever Lange's officially expressed views, he made a lasting positive impression on his Indian hosts. In the summer of 1955, when Nehru made a diplomatic visit to Poland, he supposedly said to the Polish chief of government, Józef Cyrankiewicz: "Thank you, Mr. Prime Minister, for the best gift from Poland-Professor Lange." ${ }^{44}$ Once Poland underwent the most radical

38. Oskar Lange, “Uwagi o drugim planie pięcioletnim Indii," in Pisma ekonomiczne i społeczne, 1930-1860 (Warsaw, 1961), 429-35.

39. Engerman, "The Political Power of Economic Ideas?," 124.

40. AMSZ, 12/9/218 (Notatki z pobytu w Indiach rektora SGPiS, Oskara Lange, 1956, Notatka nr. 1, 1.II.1955, npag).

41. Unger, Entwicklungspfade in Indien, chapter 2; Cullather, The Hungry World.

42. Engerman, "Learning from the East," 231.

43. AMSZ, 12/9/218 (Notatki z pobytu w Indiach rektora SGPiS, Oskara Lange, 1956, Notatka no. 1, 1.II.1955, npag).

44. Oskar Lange, Dzieła: Działalność naukowa i społeczna, vol. 8, 538. For more on Polish-Indian diplomatic relations, see Nameeta Mathur, "East meets East: Foreign Relations between India and Poland during the Cold War," South Asian History and Culture 5, no. 3 (2014): 314-27; Maciej Tumulec, Historia stosunków polsko-indyjskich XVI-XXI w., 
de-Stalinization in the eastern bloc, this connection helped enormously in forging ties with the Third World.

\section{Post-Stalinist Diplomacy and Circulation of New Economic Ideas between Poland and India}

From 1948 to 1955 "there was not a single issue with regard to which one can speak of a specifically Polish idea in comparison to foreign policy in the USSR,” writes the diplomatic historian Włodzimierz Borodziej. In 1956, however, the "model of indirect rule"-with east European nation-states as formal but not actual sovereign countries-changed, particularly in Poland. ${ }^{45}$ On March 20, at the Sixth Plenum of the Central Committee of the Polish United Workers' Party, Khrushchev announced the right to a "national path" to socialism. Polish society and many members of the PUWP received the Soviet announcement enthusiastically. But the decisive moment came on October 19, when Polish communists elected Władysław Gomułka as first secretary of the Communist Party without consulting the Soviets. Fearing that social and political unrest in Poland would lead to the disintegration of the eastern bloc, Khrushchev flew to Warsaw and faced Gomułka. ${ }^{46}$ It was a tense meeting, but the latter, as Borodziej stressed, "broke the barrier of fear," and convinced the Soviet delegation to accept the new party leadership in exchange for Polish loyalty to the eastern bloc. ${ }^{47}$ With the backing of increasingly anti-Soviet China and the ecstatic crowds in Warsaw's streets, Poland could now permit itself more attitudes and activities that diverged from the Soviet line. In striking contrast to Hungary, the Soviets did not pacify the Polish "rebellion" with tanks. Supposedly Khrushchev only complained to Gomulka that "almost all the members of the Polish Politburo have an anti-Soviet attitude and pursue such policies." 48

In what follows, I examine the ways in which Poland's de-Stalinization in political and economic policy shaped Poland's relationship with India after 1956. Poland was perhaps the only east European country in the Khrushchev era that to some extent worked toward weakening the divide between socialist and capitalist "camps" without leaving the Soviet bloc (as opposed to Yugoslavia, China, and Albania). Relations with the west improved. The United States, for instance, stepped in with loans and trade deals, and Lange served as Vice President Richard Nixon's personal guide during his visit to Poland in August 1959. ${ }^{49}$ New opportunities also opened to the east and south, although not without tensions. In China, after initially supporting the new Gomułka regime, Mao observed Poland's retreat from collectivization with displeasure. As early as the fall of 1957, he expressed concern to the Soviets

55-111; Władysław Góralski, ed., Stosunki polsko-indyjskie po drugiej wojnie światowej (chronologia i bibliografia) (Warsaw, 1985).

45. Włodzimierz Borodziej, "1956 as a Turning Point in Poland’s Foreign Policy,” in The Polish October 1956, 328-29.

46. Békés, East Central Europe 1953-1956, 347.

47. Borodziej, 331.

48. Ibid., 333.

49. Józef Winiewicz, Co pamiętam z długiej drogi życia (Poznań, 1985), 619. 
that "kulaks" and "the influence of bourgeois ideology" were very strong. ${ }^{50}$ But Nehru's India greeted the "Polish road to socialism," as Gomułka's slogan put it, with sympathy. ${ }^{51}$

In November 1956, Polish diplomats noted that "for nationally-minded Indians, Poland had become a country that is autonomous in domestic and foreign affairs" and a state that could more authentically express solidarity with the "national and anti-colonial struggle for self-determination." ${ }^{2}$ In 1957, Nehru and his economic strategist, Mahalanobis, were particularly intrigued by a new, market-oriented planning mechanism being prepared for the Polish government by Lange, his renowned colleague Michał Kalecki, and their team. In a November 1957 letter to Lange, Mahalanobis admitted that Polish debates on so-called "indicative planning" better corresponded with India's mixed economy than bureaucratized central planning. ${ }^{53} \mathrm{He}$ knew that Lange would not be offended when he referred to planning in Poland as "bureaucratized." In past private conversations in India, Lange himself had joked that Soviet planners would "look at the ceiling and then at the floor, rather than consult enterprises, to determine plan targets." ${ }^{54}$ This correspondence suggested that Poland, which suddenly became a champion of individual peasant farming and market-oriented state planning, could share with India much more than certain planning techniques.

Meanwhile, Oskar Lange transformed overnight from being an economist accused of "losing contact with reality" and a "defender of Stalinist industrialization" to a proponent of free academic discussion and socialist democratization..$^{55}$ Lange surprised the party apparatus and fellow economists by claiming that Soviet-style industrialization brought about socioeconomic "disproportions" and "an undisciplined disorder." 56 In a PUWP Central Committee meeting, Lange acknowledged that the Polish Six-Year Plan (19491955) had not improved living standards as promised. ${ }^{57}$ By the end of 1956 , Lange and Michał Kalecki became the leaders of economic reform by stepping in to chair the Economic Council. The Council proposed following Lange's interwar ideas about coordinating market mechanisms with central planning. Jokes about the arbitrariness of the Soviet-style command economy were now part of the official critique of Polish Stalinism. ${ }^{58}$

50. Shen and Li, The Polish Crisis, 111-12.

51. Hilger, "Building a Socialist Elite?," 273.

52. AMSZ, 12/27/661 (Notatka Departamentu V z dnia 29.X.1956, npag); AMSZ, 12/46/1137 (Wytyczne do wystąpień publicznych Premiera PRL w czasie wizyt w krajach Azji, npag).

53. APAN, Oskar Lange Collection, 130 (Mahalanobis to Lange, Nov. 5, 1957).

54. Archives Nationales de France, Collection EHESS, "Memoires de Charles Bettelheim," unpublished. Many thanks to Bernard Chavance for sharing a copy of these memoirs with me.

55. Oskar Lange, Dzieła: Działalność naukowa i społeczna, vol. 8, 561.

56. Oskar Lange, "Przemówienie na VII posiedzeniu KC PPZR, July 18-28 1956," in Marek Jabłonowski et al., eds., Dokumenty centralnych władz PZPR, marzec-listopad 1956 (Warsaw, 2009), 671-72. On the long-term impact of Khrushchev's Secret Speech and deStalinization in Poland, see Kolář, Der Poststalinismus.

57. Oskar Lange's speech at the 7th Plenum of the Central Committee of the PUWP, July 18-28, 1956, in Dokumenty centralnych władz PZPR, marzec-listopad 1956, 175.

58. For an economic history of the post-Stalinist period, see Zbigniew Landau and Jerzy Tomaszewski, The Polish Economy in the Twentieth Century, trans. Wojciech 
Withdrawal from the collectivization of agriculture was the most relevant part of Polish political and economic de-Stalinization. Poland's new agricultural policy constituted a negation of Stalinist principles. As early as July 1956, the co-author of the Polish version of Soviet-style collectivization, Jerzy Tepicht, publicly admitted that thousands of peasants went to jail during Stalinist collectivization for no good reason..$^{59}$ In October 1956, the new first secretary, Władysław Gomulka, announced that "the decision to disband collective farms was now left to their members." ${ }^{60}$ A massive rush to abandon kolkhozes ensued. Nine thousand of the ten thousand cooperatives spontaneously dissolved during the weeks following his pronouncement. By the end of 1956, non-state family farming generated nearly ninety percent of agricultural production in Poland. ${ }^{61}$ The fact that smallholder farming became, once again, one of the chief features of the Polish economy gave Poland a special economic status among eastern bloc countries and, unexpectedly, likened Poland to India with its "mixed economy."62

In the late 1950s, Poland officially declared India its most important "nonsocialist" partner. ${ }^{63}$ The Polish Embassy in Delhi needed experienced diplomats, most of whom had been purged during Stalinism. One such side-tracked diplomat was Juliusz Katz-Suchy, the former Polish ambassador to the United Nations (1947-51), and the brother of Ben-Zion Katz, the rector of Tel Aviv University.Juliusz Katz-Suchy was praised for his wit, eloquence, and ability to "hold a conversation instead of preaching," qualities that aimed to create a less dogmatic-meaning non-Stalinist and more liberal-diplomatic style for Poland. ${ }^{64}$ Katz-Suchy's tenure as a new ambassador to India (1957-62) thus marked a new chapter in Polish-Indian relations. India became Poland's window onto the decolonizing world, and, intellectually, a site of reflection on global underdevelopment.

\section{"The Most Difficult Thing to Establish Is a Basic Fact": Marxist Economists and the Empirical Turn}

Katz-Suchy believed that intellectual and journalistic contacts were Poland's greatest asset in foreign relations with India and other Third World countries. ${ }^{65}$

Roszkowski (London, 1985); Włodzimierz Brus and Kazimierz Łaski, From Marx to Market: Socialism in Search of an Economic System (Oxford, 1989).

59. Jerzy Tepicht's speech at the 7th Plenum of the Central Committee of the PUWP, July 18-28, 1956, Dokumenty centralnych władz PZPR, marzec-listopad 1956, 250-51.

60. Władysław Gomułka, "Speech to the 8th Plenary Session," Nowe Drogi, 10/1956, 34.

61. Jean-Charles Szurek, "Family Farms in Polish Agricultural Policy: 1945-1985," Eastern European Politics and Societies: and Cultures 1, no. 2 (1987): 225-54; Jean-Charles Szurek, Aux origines paysannes de la crise polonaise (Paris, 1982).

62. Yugoslavia had abandoned collectivization by 1953, but it had not been part of the Soviet bloc since 1948; see Swain, "Eastern European Collectivizations Campaigns Compared, 1945-1962."

63. AMSZ, 12/35/843 (Indie. Notatki polityczne.1960, Katz-Suchy to Adam Rapacki, Polish Foreign Minister, 16.VIII.1960: 122).

64. Stenogram narady centralnego aktywu partyjnego PZPR w dniach 3-4 marca 1956, in Dokumenty centralnych władz PZPR, 88.

65. AMSZ, 12/10/237 (Raporty polityczne ambasady PRL w New Delhi [za I półrocze 1958], npag); AMSZ, 12/10/226 (Raport ambasady PRL w New Delhi [za drugie półrocze 1957 r.], npag). 
As Soviet and Polish interests in India grew, the Polish Embassy in Delhi became a place where intellectual exchange on world affairs attracted both the local intelligentsia and international residents. In de-Stalinization's aftermath, many Indian politicians and foreign visitors to Delhi sought Katz-Suchy's informal opinion on eastern European and global issues. ${ }^{66}$ Katz-Suchy argued that Poland could offer incomparably more in planning expertise than other eastern bloc countries. It was clear to him, however, that Poland was significantly less powerful than India, which established its position through global Cold War rivalry and maintained profound relations with both the west and the Soviet bloc. Therefore, Poland should be "more proactive" regarding India, because "we care more about having a strong position in India, than India cares about us." 67

Katz-Suchy nominated the young, eloquent Ignacy Sachs (1927-) to disseminate Warsaw's economic thought to Indian economists and to be his eyes and ears in intellectual Indian circles. For three years, Sachs served as an intermediary between Polish luminaries in economics and other high-profile development experts who visited India. He facilitated intellectual exchanges between scholarly-minded Polish diplomats, Indian economists, and Nehru's western Marxist guests. Sachs' friendship with American social scientist Daniel Thorner was central to this circuit of knowledge. The friendship between the two, both foreigners resident in India, shows the multilateral character of expert networks in India, which went beyond bilateral diplomatic channels and Cold War political divisions. Through contact with Thorner and Indian socialist scientists, Polish economists developed a more empirical and context-sensitive approach to Third World development policies. They also expanded their role in the transcontinental Marxist conversation about rural underdevelopment that spread from Delhi via Cairo and Accra to Paris and London in decolonization's formative years.

Sachs' personal trajectory also spanned continents: his affluent and assimilated Jewish family escaped from Warsaw to Rio de Janeiro in 1939. In Brazil, he met Katz-Suchy, and eventually returned to Warsaw in 1954, where he became Katz-Suchy's assistant at the Polish Institute of International Affairs. Familiar with the economic policies of Brazil and other Latin American countries, Sachs was soon assigned to cover Asia and Africa as well, and became the key Polish expert on decolonization. ${ }^{68}$ For his first assignments, he translated the Indian constitution into Polish and prepared the Polish edition of the 1955 Bandung Conference proceedings. ${ }^{69}$ Residing in Delhi from 1957 to 1960, Sachs worked in the embassy while also pursuing graduate studies at

66. Ignacy Sachs, “My Education in Delhi” in D. School: Reflections on the Delhi School of Economics, 70. npag).

67. AMSZ, 12/10/241 (Notatka Katza-Suchego do Kolegium MSZ, December 16, 1958,

68. United Nations Intellectual History Project (UNIHP), Interview with Ignacy Sachs by Frederic Lapeyre [in French], Paris, May 9, 2000, transcript available at the Columbia University Library Special Collections.

69. Bandung: Konferencja Krajów Azji i Afryki (18-24 kwietnia 1955 r.). Dokumenty i materiały (Warsaw, 1955); Ignacy Sachs, Trzeci brzeg: w poszukiwaniu eko rozwoju (Warsaw, 2011, see also Portuguese and French editions). 
the Delhi School of Economics. He and his wife Viola, a specialist in North American literature, were allegedly the first Europeans to obtain PhDs from an Indian university. ${ }^{70}$ Later on, in La Decouverte du Tiers Monde, his major book published in 1971 in a series overseen by Ferdinard Braudel, Sachs would argue that Bandung was the most important milestone for political cooperation in modern world history. ${ }^{71}$

As a Polish embassy secretary and arranger of scientific cooperation between Poland and India, Sachs possessed privileged access to knowledge about Cold War rivalries that shaped development policy in India and other South Asian countries. Since Polish diplomacy in Delhi relied heavily on cultivating cultural and academic relations, Sachs regularly conducted conversations about India's role in the Cold War with leading Indian economists, sociologists, and journalists, reporting on these to the Polish Ministry of Foreign Affairs. In addition to politics, the talks tackled socioeconomic issues: preparations for the Third Five-Year Plan, foreign investments, land reform, and international trade. Sachs also interviewed Indian experts in rural studies on ethnic and religious tensions, the caste system, and even Indian philosophy. ${ }^{72}$ In return, Sachs briefed Indian social scientists on economic reforms and the Lange/Kalecki planning innovations that could assist India's Third Five-Year Plan. ${ }^{73}$

The intellectual affinity between Polish and Indian scholars that Sachs facilitated rested on a mutual understanding of what makes progressive nation-building "modern": the key was economics, a language common to both countries' left-wing elites. Amir Badhuri, a Bengali intellectual and proponent of Michał Kalecki, recalled that in the 1950s and 60s, "studying economics was intellectually 'fashionable' and I also felt that it would give me a better grasp of political issues." 74 Lange, Kalecki and their Indian peers knew British Keynesian macroeconomics, and had studied or worked at Oxford and Cambridge. Both groups believed that Keynesian general theory did not quite apply outside the west and that the economics' subdiscipline of development economics was needed to capture the specific circumstances of so-called "underdeveloped" countries. ${ }^{75}$ Both Polish and Indian economists rejected one-size-fits-all western theories of growth, yet, at the same time were enchanted with model-building, economic theory, and advanced

70. Sachs, Trzeci brzeg, 117.

71. Ignacy Sachs, La Decouverte du Tiers Monde (Paris, 1971). See also the English edition: The Discovery of the Third World, trans. Michael Fineberg (Cambridge, Mass., 1976); Christoph Kalter, The Discovery of the Third World: Decolonization and the Rise of the New Left in France, c. 1950-1976 (Cambridge, 2016), 1-2.

72. AMSZ, 12/10/232 (Notatki z rozmów przeprowadzanych w Warszawie, Delhi i Bombaju, different dates from 1958).

73. AMSZ 12/10/212 (Notatka z rozmowy z prof. K.N. Raj'em z Delhi School of Economics w dniu 3 listopada 1958 r. nt. trzeciego plany 5-letniego, npag).

74. Amit Badhuri (autobiographical entry) in Philip Arestis and Malcolm Sawyer, eds., A Biographical Dictionary of Dissenting Economists (1992), at digamo.free.fr/as2001. pdf (last accessed, July 1, 2018).

75. On the distinction about "monoeconomics" and "development economics," see Hirschman, "The Rise and Decline of Development Economics," in The Essential Hirschman, 49-73. 
mathematical statistics. Amartya Sen, a star of the Delhi School of Economics (and, later, a guest in Warsaw), believed that "neoclassical economics was deeply defective, but it enabled Indian economists to argue with it or run alongside."76

Above all, however, the political economic foundation of this scholarship was Marxism. "In the D. School, anyone who did not subscribe to Marxism and leftist politics was suspect," wrote the school's leading agrarian sociologist. ${ }^{77}$ As Sachs recalled of his three years in India: "To somebody coming with a Latin-American background, a reasonable knowledge of Marxian economics, and the East European experience, the confrontation was very enriching indeed." Sachs emphasized that the D. School a unique mix of advanced economic thinking, "had more to offer than any Western-based academic institution." " Immersed since his youth in the experiences of the southern hemisphere, Sachs believed that acknowledging the end of Eurocentrismprecipitated by the Shoah, which was the end point of the white, western ideal of humanity-was integral to a modern progressive sensibility. He saw India as the global center of this intellectual movement. ${ }^{79}$

One result of the transcontinental scholarly dialogue mediated by the Polish embassy was Ignacy Sachs's PhD thesis in development economics, Patterns of Public Sector in Underdeveloped Economies. Full of details of backstage debates on the execution of India's Second Five-Year Plan, the dissertation reflected the complexities and day-to-day problems of Indian planning. Sachs intended it as "a comparative study of state interventionism," specifically of Brazilian and Indian industrializations ${ }^{80}$ But the value of the SouthSouth comparison lay in the stress Sachs placed on the difficulties of economic growth politics in India and other parts of the decolonizing world, including the persistent problems of undercapitalization, and, most of all, the continuing failures of land reforms. Sachs distanced himself from dogmatic Marxist developmental economics, a position still uncommon in the late 1950s. One of the reviewers, the only tenured Marxist economist in the United States, Paul A. Baran, even rejected the thesis, calling it "bashful Marxism." 81

Sachs developed his Third-World-centric empiricism thanks to his privileged access to a network of prominent unorthodox Marxists-and above all to Daniel Thorner. Thorner (1917-74) was a resident foreign expert in Delhi and Calcutta and an economic historian of the Indian countryside. "American by birth, and Indian by adoption," Thorner was yet another left-wing Marxist

76. Amartya Sen, "On the Delhi School," in D. School, 86-102, here 94. See also his contribution published in Poland: Amartya Sen, "The Efficiency of Indirect Taxes," in Problems of Economic Dynamics and Planning: Essays in Honour of M. Kalecki (Warsaw, 1964), 365-72.

77. M.N. Srivinas, "Sociology in Delhi," in D. School, 31-50, here 44.

78. Sachs, "My Education in Delhi," in D. School, 69.

79. United Nations Intellectual History Project (UNIHP), Columbia University Special Collections, Interview with Ignacy Sachs, 11; Ignacy Sachs, "Du Moyen Age a nos jours: Européo-centrisme et découverte du Tiers Monde,” Annales. Histoire, Sciences Sociales 21, no. 3 (May-June 1966): 465-87, especially 484.

80. Ignacy Sachs, Sektor państwowy a rozwój gospodarczy (PhD diss., accepted by University of Delhi in 1960 in Polish translation (Warsaw, 1961); "My Education in Delhi," in D. School, 69.

81. Sachs, Trzeci brzeg, 126. 
scholar in India who flouted Cold War divisions, "ignored borders" and "hated injustices," as Sachs wrote. ${ }^{82}$ Like Kalecki, Sachs, and Katz-Suchy, Thorner had a Polish-Jewish background. He grew up in the United States, but after losing his job in the South Asian Studies Program at the University of Pennsylvania during the McCarthy era, he and his wife Alicia moved to India, where they worked from 1952 until 1960. Over time, Thorner and his wife became responsible for the Indian Statistical Institute's census research project, a sign of great respect on the part of Indian officials, who affectionately referred to Thorner as “an Indian economist.” In 1960, Daniel Thorner and his wife were invited by Fernard Braudel to create a new program of Indian studies in the Sixième Section de l'École Pratique des Hautes Études in Paris. ${ }^{83}$

From Thorner, Sachs learned how to combine economics with empirical and historical perspectives to engage critically with the Eurocentrism of contemporary developmental thought. ${ }^{84}$ This helped Sachs and other Warsaw scholars to focus on the predicament of smallholder farmers in India, where at the time of independence nearly eighty percent of the population lived on land or depended on agriculture. Thorner liked to rely on two historical traditions he thought were key to understanding the problems of development in Nehru's India. The first involved studies by the British colonial agronomist Harold Mann on the "Indian village" (1917-21). The other involved Russian zemstvo statistics and Aleksandr V. Chaianov's works on the peasant economy, which had circulated in India in German translations since the 1920 s. ${ }^{85}$ This body of knowledge about village betterment made plain that the peasantry's standard of living, employment, and ways of cultivating land were central to understanding India's economy and chances for economic growth. ${ }^{86}$ Thorner referred to the historical science of "land and labor" present in early twentieth-century Europe, Asia, and Africa, and argued that modernization plans required a longue durée approach.

Sachs built on Thorner's thoughts to recommend analyzing the Indian economy in light of historical regimes of land property that, he argued, had hindered postcolonial land reform. "India had a unique agrarian structure," Thorner claimed, "blending remnants from the pre-British economic order and Western concepts of private property." ${ }^{87}$ In this structure, middlemen and

82. Amiya Kumar Bagchi, “Daniel Thorner's India,” Economic and Political Weekly 16, no. 13 (March 28, 1981), 572-73, 575-78; Ignacy Sachs, "Daniel Thorner” (obituary), Economic Development and Cultural Change 24, no. 1 (October 1975): 260.

83. Sachs, "Daniel Thorner," 260.

84. Sachs, "Du Moyen Age," 486-87.

85. Daniel Thorner, The Shaping of Modern India (New Delhi, 1980), x-xv; Harold Mann and N.V. Kanitkar, Land and Labour: Deccan Village, vols. 1 and 2 (London, 1917 [Vol. 1], 1921 [Vol. 2]). On the German education of Indian intellectuals, see Kris Manjapra, Age of Entanglement: German and Indian Intellectuals across Empire (Cambridge, Mass., 2014). See also the original studies informing Harold Mann's village studies: Benjamin Seebohm Rowntree, Land and Labour: Lessons from Belgium (London, 1910).

86. Thorner preferred to talk about zamindars, coolies, or specific castes living in rural India, as he found the notion of "peasantry" too Eurocentric. Daniel Thorner, The Agrarian Prospect in India: Five Lectures on Land Reform Delivered in 1955 at the Delhi School of Economics (Bombay, 1976), 645 onward.

87. Thorner, The Agrarian Prospect in India, 7-9. 
usurers who exploited and indebted the lowest castes were the Indian village's major problems. Despite Nehru's anti-debt legislation and U.S.-sponsored experiments in community farming, the effort to undo the web of exploitation by village intermediaries failed, and contributed to recurring famines. ${ }^{88}$

Thorner's writings from the 1950s criticized epistemic practices of international development that in many ways resembled turn-of-the-twentiethcentury Methodenstreit, the methodological debate among central European economists about the importance of historical particularities and universals in economic science. ${ }^{89}$ Thorner indicted the superficiality of international development economics and its inability to study local data with historical awareness. He sarcastically divided western experts dedicated to what Albert Hirschman called "monoeconomics" into the naïve, the technocratic, and those who consciously "ignored specificity of economic backwardness in developing countries." "The toughest thing to establish for the Indian countryside was a simple fact," he stressed. ${ }^{90}$ Dismissing advisers, fellow Americans in particular, as "theoreticians," he believed that technical assistance should start "in the dust, mud, and swampy terrain of villages, while field investigators ... must have some comprehension of the larger analytical issues involved." 91 Thorner himself visited nearly a hundred villages, always arriving on foot so that villagers would not identify him as a state official or foreign aid worker. ${ }^{92}$

Thorner rediscovered this historical agrarian studies and that Sachs disseminated further to prominent scholars like Polish historian Witold Kula. Their ideas reconnected with the structuralist thinking and social statistics that had reigned in the western and non-western worlds alike before the global rise of the Soviet perspective on industrialization and the modernization theory during the early Cold War. With characteristic asperity, Thorner observed that those who studied "today's problems of the Third World seemed to be unaware that they were traversing much the same ground as several generations of Russian economists from the 1860s to the 1920s." He argued that this was why, despite multiple plans and reforms, India had changed so little. ${ }^{93}$

\section{Michał Kalecki: Welfare Development Economics and the Renewed Interest in the Rural Poor}

Thorner's structuralist sensibility overlapped with the realist empirical approach presented by Michał Kalecki (1899-1970), an international star

88. Unger, Entwicklungsphade in Indien; B. R. Tomlinson, The Economy of Modern India, in particular 138-68.

89. On twentieth-century iterations of Methodenstreit, see Daniel Speich Chasse, Die Erfindung des Bruttosozialprodukts: globale Ungleichheit in der Wissensgeschichte der Ökonomie (Göttingen, 2013).

90. Witold Kula, "Przedmowa," in Alice Thorner, Daniel Thorner and Jan Falewicz, eds., Ziemia i praca w Indii (Warsaw, 1966), 9.

91. Daniel Thorner, "Survey of the States," in The Agrarian Prospect in India, 4.

92. Ibid., 31-51.

93. Daniel Thorner, “Chayanov's concept of 'Peasant Economy', in Daniel Thorner, Basile Kerblay and R.E.F. Smith, eds., A.V. Chayanov on the Theory of Peasant Economy (Homewood, 1966), ix. 
and the symbol of the Thaw in Polish economics. Kalecki visited India for three months in late 1959. He had left the United Nations Secretariat due to McCarthyist pressures, although he had never been a member of any communist party, unlike his friend Oskar Lange. At the Second Convention of Economists in Warsaw in 1956 (at which Lange had his political conversion), Kalecki shocked the audience by his consistent rejection of Soviet economic prose, with its sloganeering language. ${ }^{94}$ Soon afterwards, Lange returned to his western-style econometrics, and Kalecki supported the retreat from the collectivization of agriculture and lectured on the importance of living standards in the politics of growth. ${ }^{95}$ These developments were on Kalecki's mind during his stay in India in 1959-60, when he insisted-though without success-that the Indian government should base its economic policy on improving the lives of the rural poor. Despite Kalecki's cool relationship with Nehru, India became one of the models for Kaleckian development economics. In the 1960s, planners and economists from Africa, Asia, and Latin America studied Kalecki's work extensively.

Kalecki did not promise miracles to his Indian hosts. On the contrary, he proposed a way of financing the Third Five-Year Plan, debated in 1959-60, that took seriously "the low living standard of the Indian masses" and India's existing political-economic regime, which he called "state capitalism." "I suggested a solution which I find neither the most justified nor most effective," Kalecki wrote in a memorandum for Nehru's government; rather, he recommended what seemed most feasible. When one Indian official asked why Kalecki did not recommend a comprehensive systemic change, he responded, "If a country wants to change the whole economic system, it makes revolution instead of inviting foreign advisors." 96

Kalecki's writings from his time in India, which were poorly received politically, informed two tenets of his internationally-influential conception of development economics. The first was his focus on the rural poor, a focus that united his prior expertise on interwar, "backward" Poland and his observation of Indian economic life. The second was the concept of the "intermediate regime," a model of the postcolonial state-capitalist economy that Kalecki based in part on experiences in Nehru's India. Kalecki reinforced an empirical and peasantry-centered approach to the politics of growth that influenced how Poles delivered development economics to the Third World in the 1960s.

94. Witczak Haugstad, A Discipline Divided, 262.

95. On the fate of the so-called "model debate," in which Lange and Kalecki played fundamental roles and which aimed to introduce market mechanisms to the centrally planned economy in post-Stalinist Poland, see Bernard Chavance, The Transformation of Communist Systems: Economic Reform Since the 1950s, trans. Charles Hauss (Boulder, 1993), 37-40; Włodzimierz Brus, "1953 to 1956: The 'Thaw' and the 'New Course'," and "1957-1963: In Search of Balanced Development” in M.C. Kaser, ed., The Economic History of Eastern Europe 1919-1975, vol. 3 (Oxford, 1986), especially $53-54$ and 71-75; J.M. Kovács \& M. Tardos eds., Reform and Transformation in Eastern Europe: Soviet-type Economics on the Threshold of Change (London, 1992).

96. Michał Kalecki, "Financial Problems of the Third Plan: Some Observations," The Economic \& Political Weekly 12, no. 28 (July 9, 1960): 1119-23. I rely on the Polish version of the document: Michał Kalecki, "Uwagi o problemach finansowych trzeciego planu pięcioletniego w Indiach,” in Dzieła, vol. 5 (Warsaw, 1985), 152-60. 
In India, Kalecki was praised as "probably the most significant of the now-neglected voices among twentieth-century economists." ${ }^{97}$ But while fellow economists admired Kalecki, politicians often gave him the cold shoulder. Kalecki left Poland in 1936 as a Rockefeller Fellow. His absence, which lasted nearly twenty years, not only saved his life-he was Jewish-but also made Kalecki an international leader in modern macroeconomics. After a short stay in Sweden in 1936, he went to England, where he worked as an academic and governmental expert in wartime Cambridge and Oxford (1937-1945). From 1946 to 1954, Kalecki worked at the United Nations Secretariat, where, in addition to contributing to many other projects, he prepared the World Economic Survey, which included an economic survey of India..$^{98}$ Despite his international fame, at home Kalecki saw his projects dismissed or rejected. In December 1959, one of Kalecki's students called the Economic Council Kalecki co-chaired "a textbook example of the rejection of an alien body in a basically preserved autocratic structure." 99 As Władysław Gomułka steered Poland away from democratization in the late 1950s, Kalecki and his collaborators compensated by undertaking development work in the Third World.

In his Indian work, Kalecki focused on the problem of rural poverty. Agriculture, in his view, was the core of welfare-oriented developmental economics-not just a resource for "primitive accumulation." Kalecki argued for a type of state interventionism that would support the poor peasantry at the expense of more prosperous rural middlemen and wealthy landowners. He deduced that the rural poor would profit from indirect taxation on goods consumed by the richer strata, an idea that Amartya Sen, the Indian Nobel Prize laureate in economics, developed further. ${ }^{100}$ Kalecki also advocated for bolder land reforms to eliminate endemic usury, together with the sizable cohort of agrarian and trade middlemen who exploited the rural poor. As noted previously, these proposals were popular among the left-wing Indian intelligentsia and progressive foreign experts like Thorner. ${ }^{101}$

What appealed to heterodox Marxist economists in India was not always in sync with the politics of Nehru's requirements. The Indian leader and his Congress Party relied on what Kalecki called "rural oligarchy," and support

97. On Kalecki's impact on international and Indian economics, see Jayati Ghosh, "Michał Kalecki," in Erik S. Reinert, Jayati Ghosh, and Rainer Kattel, eds., Handbook of Alternative Theories of Economic Development (Cheltenham, 2016), 475-86.

98. Jerzy Osiatyński, ed. Collected Works of Michat Kalecki, vols. 1 and 7, trans. Adam Kisiel (Oxford, 1997); Julio López G and Michaël Assous, Michal Kalecki (Houndmills, 2010); John Toye, "Michał Kalecki, the World Economic Report, and McCarthyism," in John Toye and Richard Toye, eds., The UN and Global Political Economy: Trade, Finance, and Development (Bloomington, 2004), 63-87; Jan Toporowski, "Shared Ideas Amid Mutual Incomprehension: Kalecki and Cambridge,” in P. Arestis, ed., Microeconomics, Macroeconomics and Economic Policy: Essays in Honour of Malcolm Sawyer (Houndmills, 2011), $170-87$.

99. Włodzimierz Brus, "Years 1957-1963: In Search of Balanced Development," in The Economic History of Eastern Europe 1919-1975, vol. 3, 71-138, here 97.

100. Amartya Sen, "The Efficiency of Indirect Taxes," in Problems of Economic Dynamics and Planning: Essays in Honour of M. Kalecki (Warsaw, 1964), 365-72.

101. Michał Kalecki, "Unemployment in Underdeveloped Countries," The Indian Journal of Labour Economics 3, no. 2 (1960): 59-61; Kalecki, "Uwagi o problemach finansowych,” 160. 
for the rural poor would not please his main constituency. Aware of this, Kalecki warned that his recommendations, if implemented, would "change the sociopolitical character of the Congress Party."102 Kalecki also failed to conform to the practices of international diplomacy. While Lange enjoyed catering to the expectations of his foreign hosts, Kalecki was inconveniently frank, which induced anxiety among diplomats and politicians. As the British Foreign Office noted (with characteristic anti-Semitic bias) Kalecki, "a small bird-like Jew, with a harsh personality and no social graces," is "not hampered by Marxist beliefs, ... is not a member of the Communist Party, and will not hesitate to advocate what he believes to be economically right." 103 According to Sachs, who assisted Kalecki during his visit to India, Nehru received the Polish economist but did not engage in any discussion concerning his memoranda, "probably in order to avoid an unpleasant exchange on land reforms." 104 In the late 1950s, the boldness of the Chinese Great Leap Forward tantalized Nehru, and Kalecki evidently wanted to curb Nehru's enthusiasm. Unfortunately, Kalecki returned to Poland politically defeated. "Kalecki was one of the greatest economists of the 20th century," one Indian historian averred, "but it does not seem that his visit was particularly fruitful for either the [Indian Statistical] Institute or the country."105

Despite his criticism of India, Kalecki sympathized with the country's political commitment to maintaining equidistance from both Cold War powers, a position he made clear in his analyses of what he called "intermediate regimes." In the late 1950s, a period of famines and social unrest, India became increasingly dependent on western food aid. Simultaneously, as western companies gained more open access to the Indian market, more luxury goods were produced in India, with no clear benefit to India's nationwide standard of living. Kalecki believed that the mere presence of the Soviet bloc countries would improve India's bargaining power with western donors. India was a classic example of an "intermediate regime" that was not headed toward socialism and remained an arena of "struggle between capitalist great powers and socialist countries." 106 Kalecki famously stated that "intermediate regimes are the proverbial clever calves that suck two cows: each gives them financial aid in competition with the other." ${ }^{107}$

The Kaleckian concept of intermediate regimes implied that socialism was not necessarily the end point of decolonization. Kalecki rejected the official Soviet narrative about Arab and African socialism and Khrushchev's assertions that a "non-capitalist path of development" would sooner or later

102. Ibid., 160.

103. Public Records Office, Foreign Office, series 371, dossier 143 203, the British ambassador on leading personalities in Poland (July 24, 1959).

104. Sachs, "My Education in Delhi," in D. School, 70.

105. Ashok Rudra, Prasanta Chandra Mahalanobis: A Biography (Delhi, 1996), 315.

106. Michał Kalecki, "Observations on Social and Economic Aspects of 'Intermediate Regimes'," Coexistence: A Review of East-West and Development Issues 4, no. 1 (1967): 1-5; for the edited version of the Polish original, see, Kalecki, "Uwagi o społecznogospodarczych aspektach 'ustrojów pośrednich'," in Dzieła, vol. 5, 22-29, here 24.

107. Michał Kalecki, "Intermediate Regimes" (1966), in his The Last Phase in the Transformation of Capitalism (New York, 1972): 121-22. 
lead to the creation of a socialist regime. The essence of intermediate regimes like India was a paradox: while the country celebrated socialist rhetoric, it also obstructed left-wing movements and the Communist Party. ${ }^{108}$ This line of thinking illustrates how Poland's post-Stalinist liberalization in politics and science enabled new interpretations of the Third World. Kalecki theorized what Sachs and Thorner presented in a historical and empirical way: that economic (and political) development in India was structurally constrained, but non-linear.

The changing political economy of decolonization corresponded with shifts in agrarian politics in Poland. De-Stalinization spurred the revival of the smallholder peasantry, Poland's poorest social group, and made Kalecki's focus on the rural poor more prominent in Polish developmental thought. This focus also revived the legacy of social research describing agrarian, interwar Poland that Kalecki gathered during the Second Polish Republic (1918-39). ${ }^{109}$ In the 1930s, he also belonged to a group of Marxist economists in Poland who developed the concept of "hidden rural unemployment." Kalecki had argued that interwar Poland required a different understanding of unemployment, one able to capture the specificity of a non-industrialized country, and in India he advocated for a separate economics for "backward" or (post-1945) "underdeveloped" countries. By reconnecting with his own interwar studies on peasant-dominated economies, Kalecki-not unlike Thorner-challenged the mainstream American modernization theory and Soviet discourse on the Third World.

\section{Conclusion: De-centering the West, or What We Can Learn from Transnational Currents of Knowledge during the Cold War}

While global Cold War rivalry in South Asia enabled Polish-Indian intellectual diplomacy, the scholarship was not merely a bipolar "Cold War science." One needs to read this scholarship through the wider historical perspective suggested by David Engerman: it is "social science in the Cold War." 110 Poland was unique in that its de-Stalinization led to the liberalization of Polish politics, foreign relations, and science, and thus made possible a more heterodox stance. Polish economists's developmental models contained a multi-layered epistemic object: the syncretic smallholder peasant, a figure which merged continents and time periods-Europe and Asia, the interwar decades, and the Cold War era. This heterodox knowledge explains, for instance, why the shift toward a critical empiricism and a focus on smallholder peasantry was not a mere offstage whisper; rather, these ideas were voiced publicly by Polish economists going to the Third World in the late 1950s and 1960s. In the Thaw's aftermath, the historical legacy of central and east European social

108. Jerzy Osiatyński, “Przypisy i dodatki,” in Dzieła, vol. 5, 315.

109. Michał Kalecki and Ludwik Landau, Szacunek dochodu społecznego w r. 1929 (Warsaw, 1934); Michał Kalecki and Ludwik Landau, Dochód spoleczny w r. 1933 i podstawy badań periodycznych nad zmianami dochodu (Warsaw, 1935).

110. David C. Engerman, “Social Science in the Cold War,” Isis 101, no. 2 (June 2010): 393-400. 
science became apparent, and the science internationalized in new ways both because and in spite of the Cold War.

Furthermore, Polish economic contributions to India were not a simple bilateral affair. On the contrary, these contributions were an important part of transnational circuits of knowledge. They were as much a part of the post-1956 revival of heterodox Marxism as they were the revival of village and peasant studies, which had simultaneously emerged in early twentieth-century Europe and colonial India. Ferdinand Braudel's well-known statement about the "peasant economy"-that it was "a distinct socioeconomic formation capable of persisting under slavery, capitalism and state socialism"-was directly informed by intellectual exchanges enabled by Nehru's global diplomacy. ${ }^{111}$ Indian debates, which engaged local scholars, foreign experts like Lange or Kalecki, and dissident western scholars like Thorner, traveled back to Europe to foster a new, more global understanding of social science. Scholars also forged new intellectual connections that cut across the politics of superpowers.

India thus became a geopolitical gateway for both the global Cold War and a multilateralism that expanded existing international networks and created new intellectual affinities between experts. In terms of official politics, the "Indian experience" contributed greatly to the institutionalization of developmental thought in communist Poland. While in Delhi, Kalecki came up with the idea of creating the Warsaw Center of Research on Underdeveloped Economies. Unsurprisingly, Kalecki ensured that Ignacy Sachs was appointed as director and Oskar Lange to the scientific board. ${ }^{112}$ The three men also created the Advanced Course in Planning for Economists from Developing Countries. From 1962 until 1968, the center trained nearly two hundred experts from Asia, Africa, and Latin America, while raising concerns among the Americans (for, arguably, its "lack of dogmatism") and causing pangs of jealousy among the Soviets. ${ }^{113}$ In the 1960s, both institutions hosted several top Indian economists-Amartya Sen, K.N. Raj, and K. Naqvi-as well as a small but highly-accomplished group of South Asian PhD students. The institutions also trained many rank-and-file functionaries, academics, and professionals who would later serve as resident technical advisers or employees in the Middle East, Africa, and Asia. The Indian network became vital in the years of political unrest of the late 1960s, especially when anti-Semitic and anti-intelligentsia purges decimated Kalecki's circle in 1968. The Thorners'

111. Fernand Braudel, “Daniel Thorner," in E.J. Hobsbawm, ed., Peasants in History: Essays in Honour of Daniel Thorner (Calcutta, 1980), xii. This Polish-French-Indian circuit of knowledge also inspired Witold Kula's famous An Economic Theory of the Feudal System: Towards a Model of the Polish Economy (London, 1976), an attempt to explain the durability of, and rationale behind, serfdom.

112. Marcin Kula, "Between Memory and Historical Enquiry: Kalecki and the Warsaw Centre of Research on Underdeveloped Economies 1962-1968," in Riccardo Bellofiore, Ewa Karwowski, and Jan Toporowski, eds., The Legacy of Rosa Luxemburg, Oskar Lange, and Michal Kalecki (Basingstoke, 2014), 165-78.

113. Ignacy Sachs, Trzeci brzeg, 130-31; Africa Institute Archives in Moscow (1966), npag. Solodovnikov's report on scholarly connections between the Soviet Union and adjacent socialist countries. Many thanks to Natalia Telepneva for sharing this document. 
Paris apartment became a refuge for Polish-Jewish scholars, Ignacy Sachs in particular, and the first station in their post-1968 careers in the west.

Finally, Polish scholars' visits to India heightened their awareness of the Eurocentrism of modern social science, and even their own Marxism. Witold Kula, a Polish Marxist historian (and friend of Kalecki and Lange), agreed with Thorner that "subjecting non-Western countries to Marxist/Western categories like 'feudalism' or 'primitive community' was a form of 'intellectual neocolonialism.'."114 In October 1957, Fernand Braudel told Kula that Polish scholars "were the only ones who can understand both the West and the East. ... What intellectual potential!" he exclaimed. ${ }^{115}$ If one attempts to understand how social science in the Soviet bloc changed in the Cold War era, in addition to the "West" and "East" to which Braudel alludes, one must also include the global South.

114. Witold Kula, "Pourquoi l'histoire européenne serait-elle universelle?" in his Rozdziatki, entry from Dec. 10, 1964 (Warsaw, 1996), 176-77.

115. Ibid., 33. 